To cite this article: De Smet, A., Mettewie, L., Galand, B., Hiligsmann, Ph., \& Van Mensel, L. (2019). Does CLIL shape attitudes and motivations? Interactions with target languages and instruction levels. International Journal of Bilingualism and Bilingual Education. DOI: 10.1080/13670050.2019.1671308

\title{
Does CLIL shape language attitudes and motivation? Interactions with target languages and instruction levels
}

\begin{abstract}
Besides being promoted as a way to improve target language proficiency, Content and Language Integrated Learning (CLIL) is also believed to positively impact socio-affective variables such as language attitudes and motivation (European Commission, 2014). Yet, few extensive empirical studies exist on these aspects in CLIL. The present contribution aims to address this gap in the literature by investigating language attitudes and motivation in CLIL on a large scale across two target languages (English and Dutch) and two instruction levels (primary and secondary). Questionnaire data were collected from 896 pupils in French-speaking Belgium measuring their language attitudes in terms of perceived easiness and attractiveness of the target language and their motivation in terms of expectancy for success, task value and cost. Results of the MANCOVAs show pupils report more positive attitudes and higher motivation in CLIL compared to non-CLIL and in English compared to Dutch. However, these differences mainly appear at secondary level, suggesting more favorable profiles develop after the fifth grade, which is the onset of formal foreign language instruction for non-CLIL pupils. Moreover, the effect sizes indicate that the target language (English vs. Dutch) plays a more crucial role than CLIL vs. non-CLIL regarding language attitudes and motivation.
\end{abstract}

Keywords: language attitudes, motivation, CLIL, English, Dutch, expectancy-value

\section{Theoretical and contextual framework}

\subsection{Language attitudes and motivation in language learning}

In its early stages, SLA research mainly focused on linguistic aptitude, as it was believed to be the main predictor of achievement in the second language, as recalled by Dörnyei (2019). However, Gardner and Lambert (1959) found that, besides aptitude, a motivational factor was equally related to achievement. Subsequent research corroborated these findings (Gardner \& Lambert, 1972) and led to the development of the socio-educational model, which integrates the influence of social milieu, individual differences (both cognitive and affective) and language acquisition contexts (formal or informal) on linguistic and non-linguistic outcomes (see Gardner, 1985).

\section{Motivation in language learning}

A key concept in the socio-educational model is the integrative motive, defined as 'a motivation to learn a second language because of positive feelings toward the community that speaks that language' (Gardner, 1985, p. 82-83). This concept is operationalized by three interrelated constructs, namely integrativeness, attitudes towards the learning situation and motivation, with the former two underlying the latter. Moreover, Gardner (1985) distinguishes two types of motivational orientations, which are the reasons that drive people to learn a second language. An 
integrative orientation reflects the wish to be part of the target language community, whereas an instrumental orientation indicates a functional or practical motivation (job, money).

Notwithstanding the importance of the socio-educational model for SLA research, it has also been criticized, mainly with respect to the concept of integrativeness (see Dörnyei, 2005). Alternatives emerged towards the end of the previous century, when established motivation theories were borrowed from psychology and applied to language learning. One example is the SelfDetermination Theory developed by Deci and Ryan (1985) and transposed to the context of SLA by Noels, Pelletier, Clément and Vallerand (2000), resulting in the Language Learning Orientations Scale (LLOS). This theory interestingly complements the socio-educational model as it distinguishes between intrinsic and extrinsic motivation. While extrinsic motivation is based on the reward or advantage that results from the learning and is therefore somewhat comparable to Gardner's instrumental orientation, intrinsic motivation means that the language learning itself interests and motivates the learner, without necessarily implying an integrative orientation towards the target language community.

Another theory inspired by psychology research is Dörnyei's $(2005,2009)$ L2 Motivational SelfSystem (L2MSS), which puts the identity dimension at the heart of second language motivation research following the theories of possible selves (Markus \& Nurius, 1986) and self-discrepancy (Higgins, 1987). Based on these theories, Dörnyei $(2005,2009)$ proposed the L2MSS, consisting of three components: the Ideal L2 Self and Ought-to L2 Self (which are the L2-specific facets of Higgins' components) and L2 Learning Experience. This theory, focusing on self-views rather than on integrativeness, has been a prominent model in $\mathrm{L} 2$ motivation research for the past decade.

Finally, the Expectancy-Value Theory is an interesting motivational framework used in psychology and educational research. According to Wigfield and Eccles (2000), learning-related variables such as performance, persistence and choice are best explained by individuals' beliefs about how well they will perform the task (expectancy for success) and the extent to which they value the task (task value). Expectancy beliefs are closely related to Bandura's (1977) concept of self-efficacy. Task value, on the other hand, has to do with incentives or reasons to engage in the activity and comprises attainment value (personal importance of doing well on the task), intrinsic value (enjoyment or interest in the task) and utility value (importance of the task for present or future goals). The distinction between intrinsic value and utility value is comparable to the one between intrinsic and extrinsic motivation. An additional component is the perceived cost of the task, including the amount of effort needed to succeed, the loss of time and energy for other valued activities and the psychological cost of failure. In their review of the literature, Barron and Hulleman (2015) argue for a revised Expectancy-Value-Cost model, distinguishing cost as a separate factor, negatively related to both expectancy and value.

Unlike the self-determination theory and theories of the self (such as possible selves and selfdiscrepancy theory), the expectancy-value model has not yet been specifically adapted to second language learning. In contrast, it has been largely used and endorsed for motivational research in educational settings, where it was found to be very effective to predict persistence, achievement and course/study choice (for a review, see Wigfield \& Cambria, 2010). While languages do differ from other school subjects in terms of their socio-cultural dimension, they also share a lot of common features and pupils are likely to view them (at least partly) as any other school subject. Hence, the expectancy-value framework, which emphasizes the relations between the self and the task at hand, could interestingly complement the currently dominant models of L2 motivation. It offers the opportunity to integrate some components of previous models (instrumental orientation, intrinsic motivation, self-relevance) and to enrich them with new components (expectancy, cost). So far, a few recent studies in SLA have successfully integrated the notion of self-efficacy, closely related to expectancy for success (Kormos, Kiddle, \& Csizér, 2011; Mills, Pajares, \& Herron, 2006, 2007; Piniel \& Csizér, 2013). In a rare study integrating an expectancy-value approach, action control 
theory and the socio-educational model, Maclntyre and Blackie (2012) found significant correlations between four non-linguistic learning outcomes (perceived communication competence, language anxiety, willingness to communicate, intention to continue language study) and all three motivational frameworks, thus supporting the potential and applicability of the expectancy-value model in L2 motivation research.

\section{Attitudes towards the target language}

Attitudes are classically defined as an evaluative orientation to any (social) object in positive/favorable or negative/unfavorable terms (Garrett, Coupland, \& Williams, 2003, p. 3). They are moulded by individual and collective experiences, ideas or stereotypes, embedded in a specific sociocultural context (Bohner, 2003, p. 241). Attitudes as social constructs are therefore dynamic and reflect feelings, thoughts, and (changing) beliefs about - in the present study - languages (Baker, 1992 , p. 9) within and across communities. Moreover, they can function as input in a social process (Garrett et al., 2003, p. 6 \& 14), like speaking or learning a language. As such, language attitudes are useful instruments to evaluate and understand (or eventually predict) positioning towards the language itself, its use, its community or its learning (situation).

Following the dominance of the socio-educational model, a vast body of SLA research has investigated language attitudes in terms of attitudes towards the target language community (as a part of integrativeness), towards the learning situation (evaluation of the teacher and the course) and towards learning the target language, as a part of motivation (Masgoret \& Gardner, 2003). Language attitudes are thus not viewed as distinct from motivation, but rather as underlying parts of motivational constructs. Yet, Mettewie (2004) stresses that attitudes should be distinguished from motivation, the latter being goal specific (e.g. motivation to learn a language) while the former remaining object specific (e.g. attitudes towards the target language or its community) (Newcomb, 1950 in Baker, 1992, p. 14). While Gardner (1985, p. 7) acknowledges that attitudes towards the target language (henceforth TL) itself (such as reactions to its sound or character or structure) might also be involved in language learning, these are not included in the measurement instrument that he developed. Consequently, few studies have looked into attitudes towards the TL itself.

Nevertheless, research in the Belgian context indicated that TL proficiency is not so much related to motivation, as suggested by Gardner's model (Masgoret \& Gardner, 2003), but rather to attitudes towards the language itself, its community, culture and contact possibilities (Mettewie, 2004, 2015): in these studies, pupils with positive attitudes towards the TL and/or its community display higher TL proficiency, whereas negative attitudes correlate with lower proficiency. In the tense socio-political context of multilingual Belgium (see Mettewie \& Van Mensel, this special issue), attitudes towards the other major language and/or community (French for Dutch-speakers and Dutch for French-speakers) tend to be neutral at best and therefore far less positive than attitudes towards English (Dewaele, 2005; Lochtman, Lutjeharms, \& Kermarrec, 2005; Mettewie \& Janssens, 2007). These findings highlight the relevance of distinguishing, within the Belgian context, TL attitudes from motivation and from attitudes towards language learning, as these are mainly shaped by individual (learning) experiences, whereas attitudes towards the TL might also be more sensitive to the macro sociopolitical context (Mettewie, 2015).

\subsection{Language attitudes and motivation in Content and Language Integrated Learning (CLIL)}

CLIL integrates the learning of content and language by teaching a part of the curriculum through the TL. The main objective of CLIL is thus twofold: for pupils to acquire subject content while at the same time developing their competence in the TL thanks to increased exposure in meaningful situations. This is also the case in the southern, French-speaking part of Belgium (Walloon Region), 
where the present study is situated (for a detailed description of the context see Mettewie \& Van Mensel, this special issue). Because of the specific officially multilingual, but socio-politically tense Belgian context, the socio-cultural benefits attributed to CLIL appear equally relevant to the linguistic ones. Indeed, the CLIL approach has repeatedly been advanced as a way to enhance motivation and improve language attitudes (Coyle, 2005; Dalton-Puffer, 2008; European Commission, 2014; Lasagabaster, 2009). Due to its authentic context for language use, its focus on meaning rather than on form, its opportunities for genuine interactions and the possible transfer to the language subject of positive attitudes towards the content subject, CLIL is believed to positively boost socio-affective factors (see Harrop, 2012, p. 62). Yet, as research has mainly been concerned with the effects of CLIL on (language) learning, the literature on socio-affective variables in CLIL is rather scarce, and mostly focus on motivation. Though the picture is rather heterogeneous and some studies do not clearly adopt a theoretical framework or only use a general measure for motivation (Seikkula-Leino, 2007; Sierra, 2011), quantitative studies tend to confirm higher motivation in CLIL compared to non-CLIL ${ }^{1}$. Most studies build on the socio-educational model, occasionally complemented by the self-determination theory, and report mean differences in favor of CLIL pupils in terms of instrumental orientation, attitudes towards learning English, effort, interest in foreign languages and intrinsic motivation, at secondary level (Doiz, Lasagabaster, \& Sierra, 2014a; Lasagabaster, 2011; Mearns, de Graaff, \& Coyle, 2017; Sylvén \& Thompson, 2015). In qualitative studies too, CLIL is reported as very motivating for both teachers and pupils in secondary school (Banegas, 2012; Denman, Tanner, \& de Graaff, 2013; Hunt, 2011). In contrast, at primary level, Lasagabaster and López Beloqui (2015) only found a positive impact of CLIL on some motivational constructs, namely intrinsic and integrative motivation, but found no significant differences for other constructs, such as extrinsic and instrumental motivation and interest in other cultures. Finally, a few studies also integrate self-related concepts. Sylvén and Thompson (2015), for instance, found higher ideal L2-self and English self-confidence in CLIL compared to non-CLIL at secondary level, whereas Seikkula-Leino (2007) found lower self-esteem in CLIL despite strong motivation to learn overall in primary school. To our knowledge, no studies have investigated motivational aspects in CLIL through the lens of expectancy-value so far.

While most of the existing research, both quantitative and qualitative, thus seems to substantiate the claim of higher motivation in CLIL, a few exceptions can be noted. For instance, some studies do not find any significant differences between CLIL and non-CLIL secondary school pupils (Amengual-Pizzaro \& Prieto-Arranz, 2014; Heras \& Lasagabaster, 2015). Other studies even report disadvantages for CLIL, with lower motivation in CLIL than in EFL in primary school (Fernández Fontecha \& Canga Alonso, 2014) and a stronger decrease in secondary school pupils' motivation over time in CLIL than in non-CLIL (Lasagabaster \& Doiz, 2017). It should be noted that the studies of Heras and Lasagabaster (2015) and Fernández Fontecha and Canga Alonso (2014) were conducted on very small samples. As to the longitudinal study by Lasagabaster and Doiz (2017), only the younger pupils - who were selected to participate in CLIL - suffered a motivational decline, whereas the older ones - who were not selected - maintained high motivation. Finally, some studies suggest a selection bias in CLIL, as pupils appear to be more interested and motivated before CLIL even started (Rumlich, 2014; Sylvén \& Thompson, 2015). This leads these authors to question whether the differences in motivation can indeed be attributed to the CLIL approach or rather to initial differences, whether due to explicit creaming and preparation in Germany (Rumlich, 2014) or to more voluntary selection in Sweden (Sylvén \& Thompson, 2015).

As to the effect of CLIL on language attitudes, even less research has been conducted. The few studies that have looked into this aspect tend to report positive differences in favor of CLIL pupils.

\footnotetext{
${ }^{1}$ The term "non-CLIL" is used for the control groups, as a contrast to the CLIL groups under investigation, and by no means intended as a derogative term for the mainstream, non-bilingual approach.
} 
For instance, in the Basque Autonomous Community of Spain, the use of English to teach content was found to be positively associated with secondary school pupils' attitudes towards English but also towards the other two languages present in the curriculum, namely Basque and Spanish (Lasagabaster \& Sierra, 2009). Navarro-Villarroel (2011) reports similar results in early EnglishSpanish immersion and Chinese World Language programs in the US, with pupils in kindergarten through second grade displaying more positive attitudes towards the two languages involved. Finally, research in French-speaking Belgium found a positive association between CLIL and language attitudes and motivation (Mettewie \& Lorette, 2014; Van de Craen, Surmont, Mondt, \& Ceuleers, 2012). Nonetheless, some very negative reactions also emerge, mostly in relation to difficulty (Coonan, 2012). This is even more the case for first-year CLIL pupils in secondary school, who are more concerned about difficulty than their older counterparts, despite a high motivation for CLIL (Doiz, Lasagabaster, \& Sierra, 2014b). Similarly, a qualitative study reports on the failure of an experimental CLIL-project in a technical and vocational secondary school in Brussels, mainly due to pupils' very negative attitudes towards Dutch, Dutch-speakers, the CLIL teacher and approach as well as lack of motivation (De Smet, 2012).

This overview of the still relatively limited literature on language attitudes and motivation in CLIL shows a less clear-cut picture than might be expected based on the aims of CLIL. While most studies report mean differences in favor of CLIL pupils, some find no significant differences between groups and others even suggest less favorable affective patterns in CLIL settings. Furthermore, this overview highlights the marked tendency of the existing literature to focus on CLIL in secondary education rather than in primary education. Moreover, with the exception of the studies conducted in English-speaking areas such as the US and the UK or in the multilingual setting of Belgium, all reported studies investigate CLIL in English.

\section{Research questions and hypotheses}

Considering the inconclusive results regarding the effect of CLIL on language attitudes and motivation, and given the fact that motivation through expectancy-value has hardly been included in CLIL research as well as the tendency for literature to focus on CLIL in English and at secondary level, the present study aims to investigate how language attitudes and motivation vary across different settings on a large scale. The precise research questions are the following:

1. How do attitudes towards the target language (TL) in terms of perceived easiness and attractiveness vary and interact according to

a) the educational approach (CLIL/non-CLIL)?

b) the TL (English/Dutch)?

c) the level of instruction (primary/secondary education)?

2. How do motivational aspects in terms of expectancy for success, perceived task value and cost vary and interact according to

a) the educational approach (CLIL/non-CLIL)?

b) the TL (English/Dutch)?

c) the level of instruction (primary/secondary education)?

Based on the literature review, we formulate three main hypotheses. First, we hypothesize both more positive language attitudes and higher motivation in CLIL compared to non-CLIL, relying on the possible benefits of the didactic approach of CLIL (see section 1.2), as well as the main tendencies in the existing literature so far. Secondly, we expect both more positive attitudes and higher 
motivation towards English than towards Dutch, based on previous research in the Belgian context (Lochtman et al., 2005; Mettewie, 2015). Thirdly, we hypothesize more positive attitudes and higher motivation in primary compared to secondary education, considering the tendency for (language learning) motivation to decrease as pupils move up the educational ladder (Chambers, 1999; Davies \& Brember, 2001; Williams, Burden, \& Lanvers, 2002).

\section{Method}

The current study is part of a larger interdisciplinary and longitudinal research project on CLIL in French-speaking Belgium (see Hiligsmann et al., 2017). The present contribution examines pupils' language attitudes and motivation across different settings, thus addressing some of the socioaffective research objectives of the project. The methodology used is largely the same as the one described in De Smet, Mettewie, Galand, Hiligsmann and Van Mensel (2018), but applied to other variables.

\subsection{Participants}

The original sample for this study consists of 896 pupils in French-medium education, learning Dutch or English as a TL through either CLIL or non-CLIL. The pupils were in the fifth year of primary (Grade 5 , mean age 10.5 years old) or secondary school (Grade 11, mean age 16.5 years old). They came from 13 primary and 9 secondary schools across French-speaking Belgium, selected in order to obtain diversity regarding location, socio-economic level and organizing authority.

Table 1 displays the participants' background characteristics. Bilingualism refers to the language dominance of the pupils outside school and shows that $93.2 \%$ speaks French (64.9\% exclusively and $28.3 \%$ in combination with another unspecified language). The sample is well balanced in terms of gender. As in many studies (Entwisle \& Astone, 1994), the highest degree of the mother was used as a proxy of participants' socio-economic status (SES) and comparisons revealed significantly higher SES in CLIL, in secondary classes and in Dutch as a TL compared to English. Pupils' nonverbal intelligence was measured through Raven's Standard Progressive Matrices (Raven, Court, \& Raven, 1998), indicating means in accordance with the norms for the respective ages of the participants, but also significantly higher non-verbal intelligence scores in CLIL and in Dutch compared to English (for details see Simonis, Van der Linden, Galand, Hiligsmann, \& Szmalec, 2019). Finally, 15.2\% of the participants reported having been retained at least one year in their curriculum, with again a more favorable profile in CLIL and for Dutch as a TL. Quite logically there is also less grade retention at primary level than at secondary level. Considering the significant differences between groups for SES, nonverbal intelligence and grade retention (for a discussion see Van Mensel, Hiligsmann, Mettewie, \& Galand, 2019), it is crucial to control for these variables in further analyses.

Table 1 Distribution and background characteristics of the sample $(\mathrm{N}=896)$

\begin{tabular}{|c|c|c|c|c|c|c|c|c|c|c|c|c|c|}
\hline & \multirow{3}{*}{$\begin{array}{l}N \\
97 \\
9\end{array}$} & \multicolumn{3}{|c|}{ Bilingualism (\%) } & \multicolumn{2}{|c|}{ Gender (\%) } & \multicolumn{3}{|c|}{ SES (\%) } & \multirow{2}{*}{$\begin{array}{l}\text { Non- } \\
\text { verbal } \\
\text { intelli- } \\
\text { gence } \\
(\mathrm{M})^{2}\end{array}$} & \multirow{2}{*}{$\begin{array}{c}\text { Grade } \\
\text { retentio } \\
\mathrm{n}(\%)\end{array}$} \\
\hline & & & & French & $\begin{array}{c}\text { French + } \\
\text { other }\end{array}$ & $\begin{array}{l}\text { Mostly } \\
\text { other }\end{array}$ & Female & Male & Low & Medium & High & & \\
\hline \multirow{3}{*}{$\begin{array}{ll}\frac{1}{2} & \pi \\
\frac{\pi}{\pi} & 0 \\
\frac{5}{2} & \frac{0}{2} \\
0 & 0\end{array}$} & \multirow{2}{*}{ 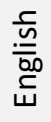 } & Non-CLIL & & 58.3 & 30.2 & 11.5 & 52.6 & 47.4 & 53.5 & 26.8 & 19.7 & 25.95 & 26.6 \\
\hline & & CLIL & 102 & 53.9 & 38.2 & 7.8 & 41.2 & 58.8 & 22.6 & 38.1 & 39.3 & 29.34 & 6.9 \\
\hline & 菊 & Non-CLIL & 68 & 44.1 & 42.6 & 13.2 & 51.5 & 48.5 & 45.8 & 32.2 & 22.0 & 28.63 & 16.7 \\
\hline
\end{tabular}

\footnotetext{
${ }^{2}$ Ranging from 0 to a maximum score of 60 .
} 


\begin{tabular}{|c|c|c|c|c|c|c|c|c|c|c|c|c|c|}
\hline & & CLIL & 174 & 66.1 & 29.9 & 4.0 & 57.5 & 42.5 & 14.3 & 5.1 & 50.6 & 30.25 & 2.9 \\
\hline \multirow{4}{*}{ 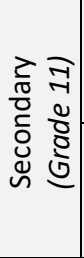 } & \multirow{2}{*}{ 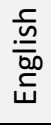 } & Non-CLIL & 102 & 67.6 & 26.5 & 5.9 & 59.8 & 40.2 & 36.4 & 44.2 & 19.5 & 41.82 & 24.8 \\
\hline & & CLIL & 100 & 64.0 & 25.0 & 11.0 & 55.0 & 45.0 & 19.8 & 44.4 & 19.5 & 43.67 & 20.0 \\
\hline & \multirow{2}{*}{ 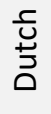 } & Non-CLIL & 113 & 69.9 & 26.5 & 3.5 & 56.6 & 43.4 & 28.4 & 38.2 & 33.3 & 42.41 & 25.9 \\
\hline & & CLIL & 140 & 80.7 & 15.7 & 3.6 & 45.0 & 55.0 & 10.1 & 31.8 & 58.1 & 46.04 & 9.3 \\
\hline \multicolumn{3}{|c|}{ Total } & 896 & 64.9 & 28.3 & 6.8 & 52.6 & 47.4 & 25.4 & 36.2 & 38.4 & 36.94 & 15.2 \\
\hline
\end{tabular}

At the moment of the data collection, the vast majority of the CLIL pupils at primary level had been in the CLIL-track for 4 or 5 years (16\% from the first year of primary school on and $68 \%$ from last year of kindergarten on). At secondary level, $64 \%$ were considered to be late CLIL pupils, as they started CLIL in the first year of secondary school (4 years of CLIL), while $23 \%$ had been part of a CLIL class for 10 to 11 years, having started at primary school and considered to be early CLIL pupils. The rest of the CLIL pupils joined the program at different moments. In the present study, the distinction between early and late CLIL will not be included into the analyses for methodological reasons.

The non-CLIL pupils were supposed to have started the learning of their first foreign language (English or Dutch) in the $5^{\text {th }}$ grade of primary school (i.e. just before the data collection) as regulated in that area of Belgium (see Mettewie \& Van Mensel, this special issue). This was the case for $74 \%$ of the pupils learning English (26\% started earlier). However, only $28 \%$ of the Dutch learners reported having started in Grade 5, as most of these pupils (41\%) said they already learned Dutch in the first year of primary school and $15 \%$ even during kindergarten. The diversity in the age of onset was confirmed by the data at secondary level, with $33 \%$ having started English when entering secondary school (Grade 7), 19\% in Grade 9 and about half of them at some point during primary school. For our Dutch sample, we noted that $88 \%$ of the pupils had started learning Dutch prior to secondary education, with again a wide range of starting moments.

These figures illustrate that the starting moment for FL learning is less clear cut than expected, probably due to the fact that parents and schools often start foreign language classes or activities (within or outside school) before the compulsory age and that pupils are allowed to switch TL as a main foreign language during their school trajectory. Therefore, we will not be able to include the years of FL learning in the analyses.

\subsection{Instrument and procedure}

The instrument for this study consisted of an extensive self-report questionnaire measuring, among other socio-affective variables, pupils' language attitudes and motivation, along with background information such as socio-demographic variables, school trajectories and linguistic background. Items measuring attitudes towards the TL were inspired by Mettewie's scales (2004), adapted from Sharp, Thomas, Price, Francis and Davies (1973) and Baker (1992). The items were formulated as semantic differentiators, with the negative end coded as 1 and the positive end coded as 7 . Exploratory factor analyses revealed two underlying constructs, namely perceived attractiveness and perceived difficulty of the TL, which was renamed perceived easiness in order to have two positive scales. Reliability analyses showed satisfactory internal consistency for both scales. This resulted in one 6-item scale measuring perceived easiness $(\alpha=.835)$ and one 3 -item scale measuring perceived attractiveness of the TL $(\alpha=.877)$ and are in line with previous results (Mettewie, 2015).

Motivation was measured in terms of expectancy for success, perceived task value and cost, based on the motivational framework of expectancy-value theory (Wigfield \& Eccles, 2000). The scales were constructed from existing adaptations in French (Galand \& Hospel, 2015) and measured as 7-point Likert scales, ranging from strongly disagree (1) to strongly agree (7). Exploratory factor 
analyses supported the distribution of the selected items into their respective scales. Reliability analyses indicated satisfactory internal consistency for all scales. This resulted in one 5-item scale measuring expectancy for success $(\alpha=.759)$, one 8 -item scale measuring perceived task value $(\alpha=$ $.854)$, and one 3-item scale measuring perceived cost $(\alpha=.711)$.

The questionnaire was administered in two slightly different versions, as items were adapted according to pupils' TL (English or Dutch). All items were, however, formulated in French (see appendix), the main language of education and most pupils' first language. The questionnaire was completed during school hours in pen-and-paper format.

\subsection{Data analysis}

The data were analyzed using the Statistical Package for Social Sciences (SPSS) 24. Data were explored by the means of descriptive and correlational analyses. Next, two multivariate analyses of covariance (MANCOVA $2 \times 2 \times 2$ ) were conducted in order to answer the research questions. The first analysis targeted the language attitudes, with the computed factors of perceived easiness and attractiveness of the TL as dependent variables. The second analysis investigated the motivational profiles, with the computed factors of expectancy for success, perceived task value and cost as the three dependent variables. In both cases, the three grouping variables 'educational approach (nonCLIL/CLIL)', 'TL (English/Dutch)' and 'instruction level (primary/secondary)' were included as fixed factors and five background variables (bilingualism, gender, socio-economic status (SES), nonverbal intelligence and grade retention) were added to the analyses as covariates. While the overall sample counts 896 participants, the multivariate analyses were conducted with 681 or 682 participants (see Table 4 and 6 ) due to approximately $15 \%$ of missing values for SES (collected through a questionnaire from parents) and approximately $11 \%$ of missing values for nonverbal intelligence (collected on computers at the university), of which approximately $2 \%$ of missing values overlapped. In the case of significant interactions between grouping variables, post hoc tests were conducted using Bonferroni's correction to compare the main effects.

\section{Results}

The results of the descriptive analyses are summarized in Table 2. Overall, pupils perceive their TL as relatively easy (4.46) and rather attractive (5.22). With respect to the motivational aspects, the overall means indicate rather high expectancy for success (5.30) and perceived task value (4.97) and low perception of cost (2.55).

Table 2 Descriptive analyses

\begin{tabular}{|c|c|c|c|c|c|c|c|c|c|c|c|c|c|}
\hline & \multirow{2}{*}{$\mathbf{N}$} & \multicolumn{2}{|c|}{ Easiness } & \multicolumn{2}{|c|}{ Attractiveness } & \multicolumn{2}{|c|}{ Expectancy } & \multicolumn{2}{|c|}{ Value } & \multicolumn{2}{|c|}{ Cost } \\
\hline & & & & $M$ & SD & $M$ & SD & $M$ & SD & $\mathrm{M}$ & SD & $\mathrm{M}$ & SD \\
\hline \multirow{4}{*}{$\frac{\text { }}{\underset{\alpha}{\alpha}}$} & \multirow{2}{*}{ English } & non-CLIL & 97 & 3.98 & 1.39 & 6.08 & 0.97 & 5.47 & 1.00 & 5.42 & 1.14 & 2.65 & 1.58 \\
\hline & & CLIL & 102 & 4.68 & 1.35 & 6.06 & 0.87 & 5.51 & 1.02 & 5.49 & 1.03 & 2.27 & 1.22 \\
\hline & \multirow{2}{*}{ Dutch } & non-CLIL & 68 & 4.10 & 1.31 & 5.33 & 17 & 32 & 0.95 & 4.70 & 1.33 & 2.84 & 1.25 \\
\hline & & CLIL & 174 & 4.50 & 1.37 & 5.36 & 1.17 & 5.43 & 1.00 & 4.96 & 1.08 & 2.52 & 1.35 \\
\hline \multirow{4}{*}{ 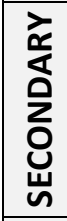 } & \multirow{2}{*}{ English } & non-CLIL & 102 & 4.81 & 1.01 & 6.16 & 0.95 & 5.32 & 0.96 & 5.24 & 0.97 & 2.34 & 1.23 \\
\hline & & CLIL & 100 & 5.45 & 0.94 & 6.49 & 0.71 & 5.72 & 0.82 & 5.70 & 0.79 & 1.73 & 0.76 \\
\hline & \multirow{2}{*}{ Dutch } & non-CLIL & 113 & 3.68 & 1.09 & 3.17 & 1.17 & 4.59 & 1.20 & 3.82 & 1.28 & 3.47 & 1.46 \\
\hline & & CLIL & 140 & 4.42 & 0.99 & 3.88 & 1.02 & 5.08 & 0.89 & 4.61 & 0.92 & 2.61 & 1.12 \\
\hline \multicolumn{3}{|c|}{ TOTAL } & 896 & 4.46 & 1.29 & 5.22 & 1.52 & 5.30 & 1.03 & 4.97 & 1.20 & 2.55 & 1.34 \\
\hline
\end{tabular}

Note: All scales range from 1 to 7 . 
Regarding the relationships between the five variables under scrutiny, Table 3 shows that all variables are significantly (negatively) correlated, with medium to large associations.

Table 3 Pearson correlations (*** $p<.001,2$-tailed)

\begin{tabular}{|l|c|c|c|c|c|}
\hline & Easiness & Attractiveness & Expectancy & Value & Cost \\
\hline Easiness & 1 & & & & \\
\hline Attractiveness & $.425^{* * *}$ & 1 & & & \\
\hline Expectancy & $.476^{* * *}$ & $.411^{* * *}$ & 1 & & \\
\hline Value & $.446^{* * *}$ & $.640^{* * *}$ & $.581^{* * *}$ & 1 & \\
\hline Cost & $-.339^{* * *}$ & $-.393^{* * *}$ & $-.409^{* * *}$ & $-.460^{* * *}$ & 1 \\
\hline
\end{tabular}

\subsection{Perceived easiness and attractiveness of the target language}

The MANCOVA for perceived easiness and attractiveness of the TL showed significant effects of three covariates: bilingualism, gender and socio-economic status, while no significant effects were found for nonverbal intelligence and grade retention. Over and above these background effects, the analysis revealed significant main effects for the three grouping variables, namely $\operatorname{TL}(F(667,2)=$ 208.62; $\left.p<.001 ; \eta^{2} p=.38\right)$, instruction level $\left(F(667,2)=42.80 ; p<.001 ; \eta^{2} p=.11\right)$, and educational approach $\left(F(667,2)=24.03 ; p<.001 ; \eta^{2} p=.07\right)$. These main effects are qualified by two significant two-way interactions: one between TL and level $\left(F(667,2)=81.16 ; p<.001 ; \eta^{2} p=.20\right)$, and the other between approach and level $\left(F(667,2)=5.68 ; p<.01 ; \eta^{2} p=.02\right)$.

At the univariate level, the analyses (summarized in Table 4) revealed significant effects of bilingualism for perceived easiness (with bilinguals perceiving the TL as easier than monolinguals) and of gender and socio-economic status for perceived attractiveness (with higher perceived attractiveness among girls than boys and among pupils with lower SES compared to pupils with higher $\mathrm{SES}^{3}$ ). Beyond these background effects, significant main effects of educational approach, TL and instruction level were found for both perceived easiness and attractiveness of the TL. These main effects indicate that pupils perceive their TL as both easier and more attractive in CLIL compared to non-CLIL and in English compared to Dutch (see means in Table 5). Regarding instruction level, secondary school pupils perceive the TL as easier but less attractive compared to primary school pupils.

Table 4 Univariate ANCOVA for Easiness and Attractiveness $(* * p<.01, * * * p<.001)$

\begin{tabular}{l|c|c|c|c|}
\cline { 2 - 5 } & \multicolumn{2}{|c|}{ Easiness } & \multicolumn{2}{c|}{ Attractiveness } \\
Source & $\mathrm{F}$ & $\eta^{2}{ }_{p}$ & $\mathrm{~F}$ & $\eta^{2}{ }_{p}$ \\
\hline Corrected Model & $12.18^{* * *}$ & .179 & $78.22^{* * *}$ & .584 \\
\hline Intercept & $179.80^{* * *}$ & .212 & $531.74^{* * *}$ & .443 \\
\hline Bilingualism & $\mathbf{2 4 . 5 0 ^ { * * * }}$ & .035 & 2.41 & .004 \\
\hline Gender & 0.12 & .000 & $10.24^{* *}$ & .015 \\
\hline Socio-economic status & 0.30 & .000 & $\mathbf{7 . 7 5}$ & .011 \\
\hline Nonverbal intelligence & 0.01 & .000 & 0.00 & .000 \\
\hline
\end{tabular}

\footnotetext{
${ }^{3}$ While higher perceived attractiveness of the TL among pupils with lower SES seems counterintuitive, the explanation lies in (a) the significantly higher SES amongst pupils learning Dutch compared to English (see section 3.1) and (b) the significantly higher attractiveness of English compared to Dutch (see Table 5).
} 


\begin{tabular}{|c|c|c|c|c|}
\hline Grade retention & 0.07 & .000 & 0.73 & .001 \\
\hline Educational approach & $44.01^{* * *}$ & .062 & $18.27^{* * *}$ & .027 \\
\hline Target language & $25.82^{* * *}$ & .037 & $411.50^{* * *}$ & .381 \\
\hline Instruction level & $6.80^{* *}$ & .010 & $53.43^{* * *}$ & .074 \\
\hline Approach x TL & 0.11 & .000 & 3.51 & .005 \\
\hline Approach $x$ Level & 0.63 & .001 & $11.16^{* *}$ & .016 \\
\hline TL x Level & $27.39^{* * *}$ & .039 & $162.13^{* * *}$ & .195 \\
\hline Approach x TL x Level & 0.34 & .001 & 0.09 & .000 \\
\hline Error & \multicolumn{2}{|c|}{669} & \multicolumn{2}{|c|}{668} \\
\hline Total & \multicolumn{2}{|c|}{682} & \multicolumn{2}{|c|}{681} \\
\hline Corrected Total & \multicolumn{2}{|c|}{681} & \multicolumn{2}{|c|}{680} \\
\hline
\end{tabular}

Table 5 Estimated marginal means for Easiness and Attractiveness

\begin{tabular}{|l|c|c|c|c|c|c|} 
& \multicolumn{2}{|c|}{ Approach } & \multicolumn{2}{c|}{ TL } & \multicolumn{2}{c|}{ Level } \\
\cline { 2 - 8 } & non-CLIL & CLIL & English & Dutch & Primary & Secondary \\
\hline Easiness TL & 4.07 & $\mathbf{4 . 7 3}$ & $\mathbf{4 . 6 4}$ & 4.16 & 4.22 & $\mathbf{4 . 5 7}$ \\
\hline Attractiveness TL & 5.13 & $\mathbf{5 . 5 0}$ & $\mathbf{6 . 1 4}$ & 4.49 & $\mathbf{5 . 7 3}$ & 4.90 \\
\hline
\end{tabular}

These main effects are qualified by significant two-way interactions (see Table 4).

Regarding perceived easiness of the TL (triangles in Figure 1), post hoc tests on the interaction between TL and level $\left(\eta^{2}{ }_{p}=.039\right)$ show that only secondary school pupils with English as a TL, perceive English as much easier than those with Dutch as a TL (indicated by ${ }^{* * *}$ ), as none of the three other groups differ significantly from each other.

As to perceived attractiveness of the TL (squares in Figure 1), post hoc tests on the strong interaction between TL and level $\left(\eta^{2}{ }_{p}=.195\right)$ indicate that only pupils learning Dutch report low attractiveness for Dutch at secondary level $(M=3.56)$, whereas at primary level the pupils consider Dutch to be clearly attractive ( $M=5.42)$, though still less attractive than English as a $T L$, where no differences are found between primary and secondary school.

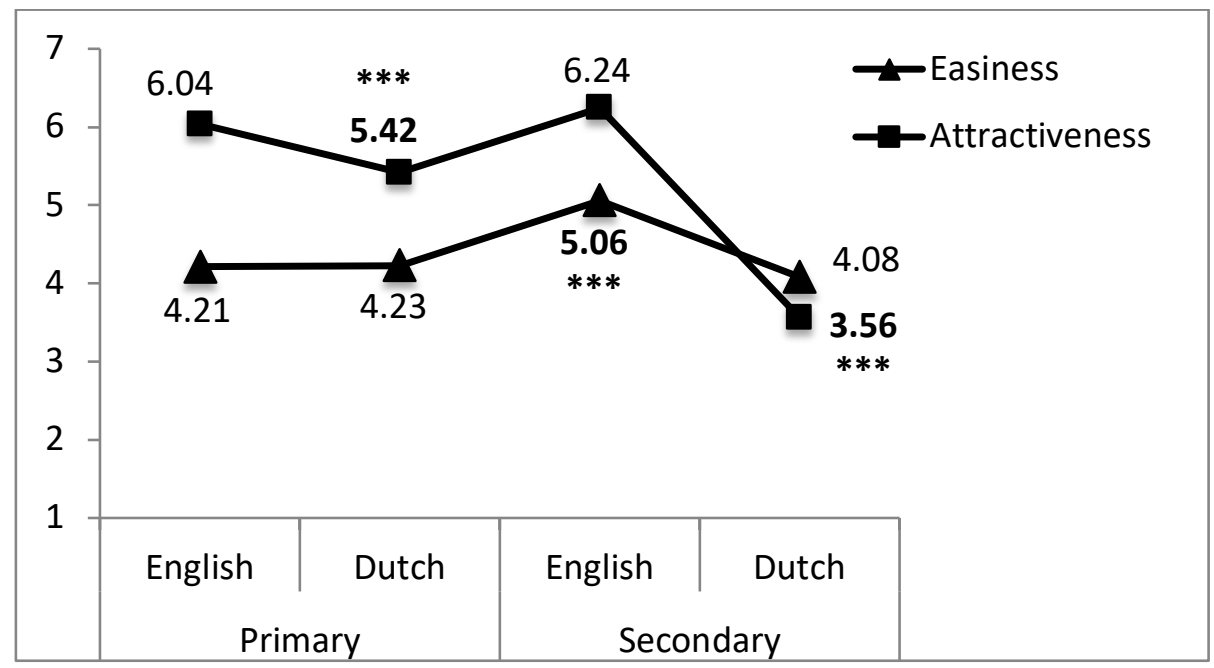

Figure 1 Interaction TL x Level for Easiness and Attractiveness 


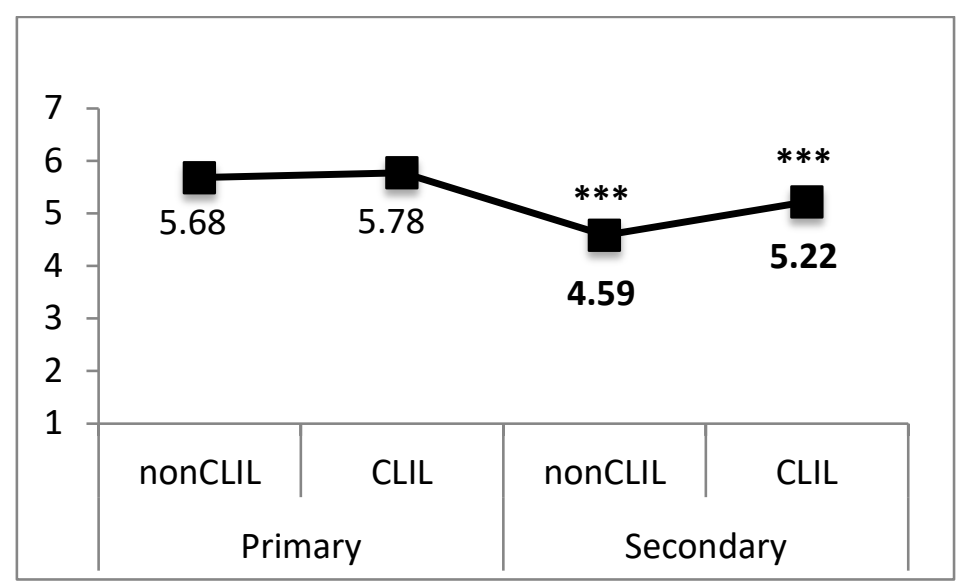

Figure 2 Interaction Approach x Level for Attractiveness

Figure 2 visualises the interaction for the perceived attractiveness of the $T L$, indicating that the main effect of educational approach in favor of CLIL $\left(\eta^{2}{ }_{p}=.027\right)$ only appears at secondary level. This means only secondary school pupils report significantly higher attractiveness of the TL in CLIL compared to non-CLIL, as at primary level all pupils perceive their TL as highly attractive.

\subsection{Expectancy for success, task value and cost}

The MANCOVA for expectancy, value and cost showed significant effects for two covariates: bilingualism and gender, while no significant effects were found for socio-economic status, nonverbal intelligence and grade retention. Over and above these background effects, the analysis revealed significant main effects for two of the three grouping variables, namely $\operatorname{TL}(F(667,3)=$ 41.99; $\left.p<.001 ; \eta^{2}=.16\right)$ and educational approach $\left(F(667,3)=9.36 ; p<.001 ; \eta^{2} p=.04\right)$. These main effects are qualified by three significant two-way interactions between (a) TL and level $(F(667,3)=$ 7.92; $\left.p<.001 ; \eta^{2}{ }_{p}=.03\right)$, (b) approach and level $\left(F(667,3)=5.82 ; p<.01 ; \eta^{2}=.0 .3\right)$ and (c) approach and $\operatorname{TL}\left(F(667,3)=3.67 ; p<.05 ; \eta_{p}^{2}=.02\right)$.

At the univariate level, the analyses (summarized in Table 6) revealed significant effects of bilingualism (with bilinguals reporting higher expectancy for success and higher task value than monolinguals) and gender (with girls reporting higher task value and lower cost than boys). Beyond these background effects, main effects indicate significantly higher expectancy for success and task value in CLIL compared to non-CLIL, in English compared to Dutch and in primary compared to secondary education (see means in Table 7). Pupils also report significantly lower cost in CLIL and in English as a TL, but there were no differences between primary and secondary level.

Table 6 Univariate ANCOVA for Expectancy, Value and Cost $(* p<.05, * * p<.01, * * * p<.001)$

\begin{tabular}{|l|c|c|c|c|c|c|}
\cline { 2 - 7 } & \multicolumn{2}{|c|}{ Expectancy } & \multicolumn{2}{c|}{ Value } & \multicolumn{2}{c|}{ Cost } \\
\hline Source & $\mathrm{F}$ & $\eta^{2}{ }_{p}$ & $\mathrm{~F}$ & $\eta_{p}{ }_{p}$ & $\mathrm{~F}$ & $\eta_{p}{ }_{p}$ \\
\hline Corrected Model & $8.51^{* * *}$ & .132 & $21.66^{* * *}$ & .280 & $9.95^{* * *}$ & .151 \\
\hline Intercept & $467.14^{* * *}$ & .411 & $405.66^{* * *}$ & .377 & $48.23^{* * *}$ & .067 \\
\hline Bilingualism & $4.87^{*}$ & .007 & $14.09^{* * *}$ & .021 & 0.00 & .000 \\
\hline Gender & 0.41 & .001 & $4.22^{*}$ & .006 & $5.89^{*}$ & .009 \\
\hline Socio-economic status & 0.73 & .001 & 0.61 & .001 & 0.29 & .000 \\
\hline Nonverbal intelligence & 1.41 & .002 & 1.82 & .003 & 0.01 & .000 \\
\hline Grade retention & 0.22 & .000 & 0.23 & .000 & 2.71 & .004 \\
\hline
\end{tabular}




\begin{tabular}{|c|c|c|c|c|c|c|}
\hline Educational approach & $11.00^{* *}$ & .016 & $21.38^{* * *}$ & .031 & $16.90^{* * *}$ & .025 \\
\hline Target language & $23.54^{* * *}$ & .034 & $115.75^{* * *}$ & .148 & $43.64^{* * *}$ & .061 \\
\hline Instruction level & $4.36^{*}$ & .006 & $5.43^{*}$ & .008 & 0.71 & .001 \\
\hline Approach $\mathrm{x}$ Language & 2.86 & .004 & $10.47^{* *}$ & .015 & 3.58 & .005 \\
\hline Approach x Level & $9.43^{* *}$ & .014 & $13.09^{* * *}$ & .019 & $9.57^{* *}$ & .014 \\
\hline Language $x$ Level & $11.77^{* *}$ & .017 & $15.08^{* * *}$ & .022 & $16.28^{* * *}$ & .024 \\
\hline Approach $x$ Language $x$ Level & 0.01 & .000 & 0.16 & .000 & 0.00 & .000 \\
\hline Error & \multicolumn{2}{|c|}{669} & \multicolumn{2}{|c|}{669} & \multicolumn{2}{|c|}{669} \\
\hline Total & \multicolumn{2}{|c|}{682} & \multicolumn{2}{|c|}{682} & \multicolumn{2}{|c|}{682} \\
\hline Corrected Total & \multicolumn{2}{|c|}{681} & \multicolumn{2}{|c|}{681} & \multicolumn{2}{|c|}{681} \\
\hline
\end{tabular}

Table 7 Estimated marginal means for Expectancy, Value and Cost

\begin{tabular}{|l|c|c|c|c|c|c|}
\multirow{2}{*}{} & \multicolumn{2}{|c|}{ Approach } & \multicolumn{2}{c|}{ Language } & \multicolumn{2}{c|}{ Level } \\
\cline { 2 - 8 } & non-CLIL & CLIL & English & Dutch & Primary & Secondary \\
\hline Expectancy & 5.16 & $\mathbf{5 . 4 3}$ & $\mathbf{5 . 4 9}$ & 5.10 & $\mathbf{5 . 4 1}$ & 5.18 \\
\hline Value & 4.81 & $\mathbf{5 . 2 1}$ & $\mathbf{5 . 4 6}$ & 4.56 & $\mathbf{5 . 1 5}$ & 4.88 \\
\hline Cost & 2.66 & $\mathbf{2 . 2 4}$ & $\mathbf{2 . 1 3}$ & 2.78 & 2.39 & 2.51 \\
\hline
\end{tabular}

These main effects are qualified by significant two-way interactions (see Table 6). Post hoc tests on the interactions between language and level (see Figure 3) show that secondary school pupils learning Dutch report significantly lower expectancy for success, lower task value and higher cost than the other three groups. For participants with English as a TL, no significant differences for the motivational variables appeared between primary or secondary level, contrary to pupils learning Dutch in primary school who report significantly higher task value $(M=4.86)$ than those in secondary school $(M=4.26)$, but still significantly less than pupils learning English (whether at primary or secondary level). In sum, the main effects of TL are in favor of English at secondary level, meaning only secondary school pupils report lower expectancy for success and task value as well as higher cost for Dutch.

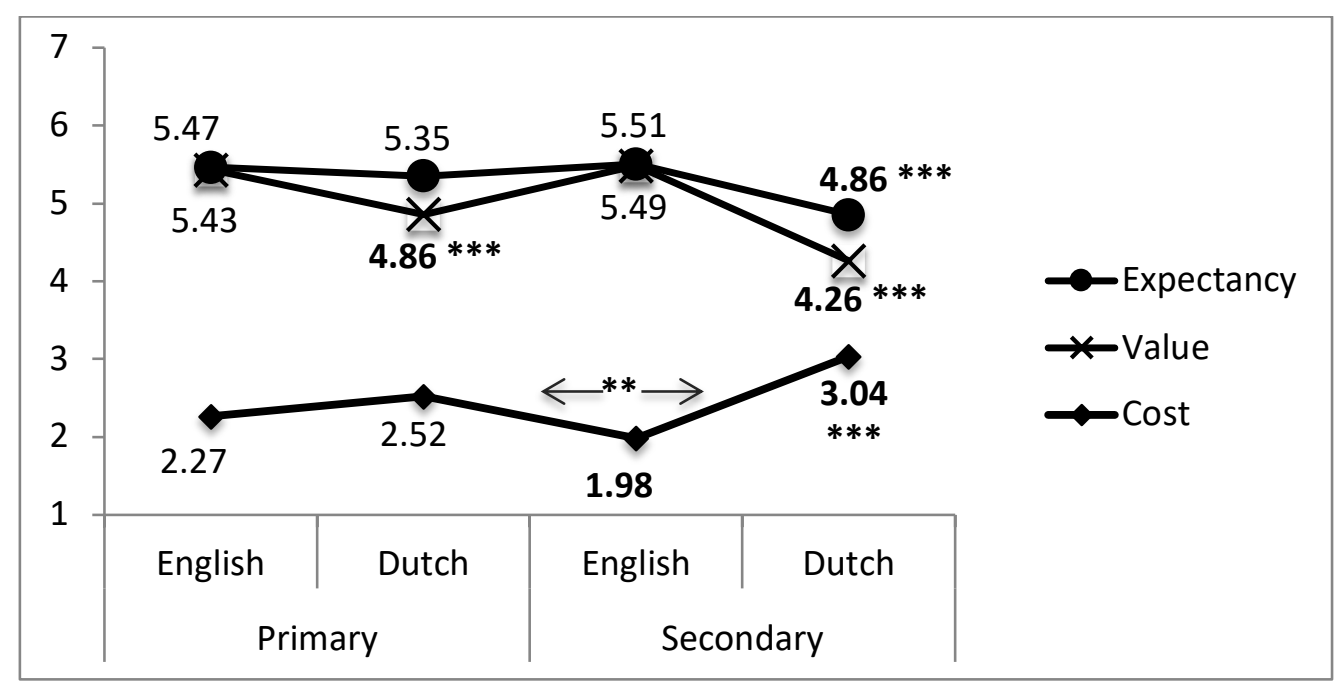

Figure 3 Interaction TL x Level for Expectancy, Value and Cost

For the interactions between approach and level (see Figure 4), post hoc tests indicate that the main effects of educational approach in favor of CLIL only appear at secondary level, implying only 
secondary school pupils perceive lower task value, lower expectancy for success and higher cost in non-CLIL compared to CLIL.

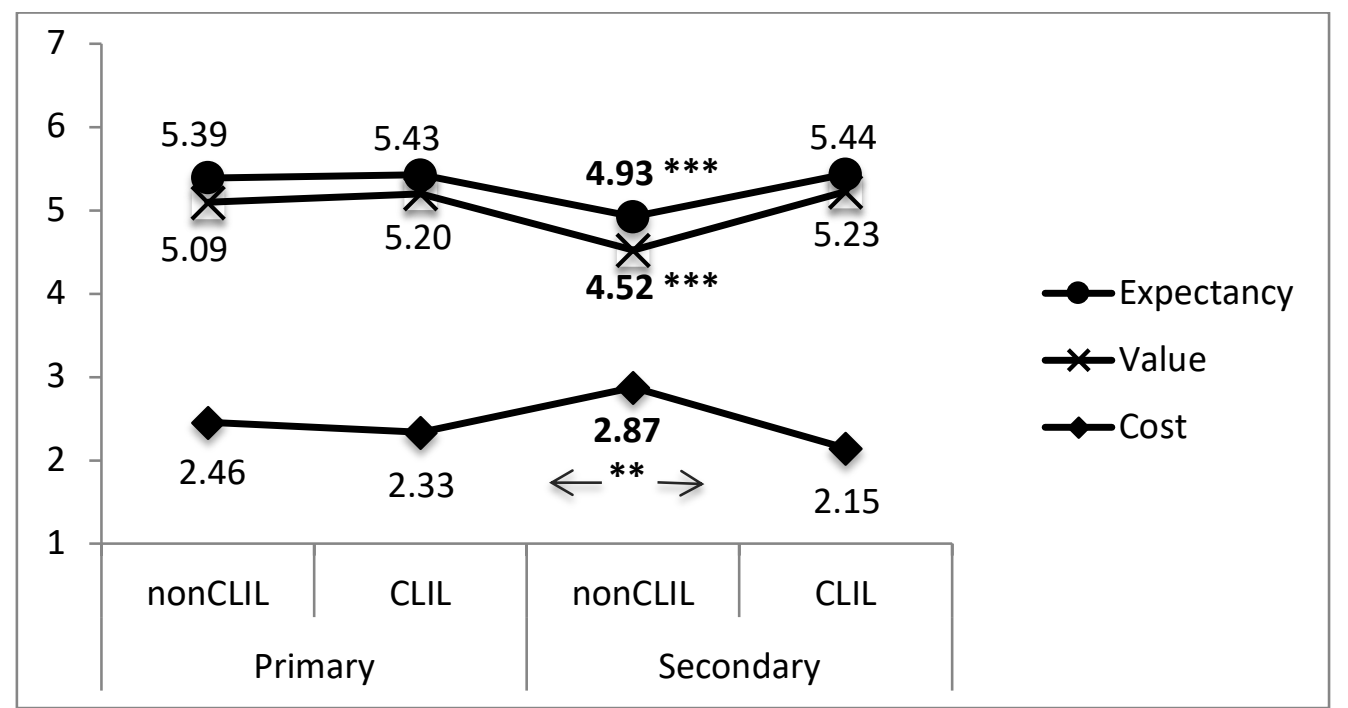

Figure 4 Interaction Approach $\mathrm{x}$ Level for Expectancy, Value and Cost

Finally, post hoc tests on the interaction between approach and TL reveal that non-CLIL pupils learning Dutch report significantly lower task value $(M=4.22)$ than the other three groups (see Figure 5). Pupils learning Dutch through CLIL report significantly higher task value $(M=4.90)$, but still significantly less than pupils learning English, whether in CLIL ( $M=5.53$ ) or non-CLIL ( $M=5.39$ ). As there is no significant difference between the English learners, the main effect of educational approach for task value $\left(\eta^{2}{ }_{p}=.015\right)$ in favor of CLIL only appears for Dutch. This means only pupils learning Dutch in non-CLIL perceive lower task value compared to pupils in CLIL. These results are in line with the previous interactions described for both motivational and attitudinal variables.

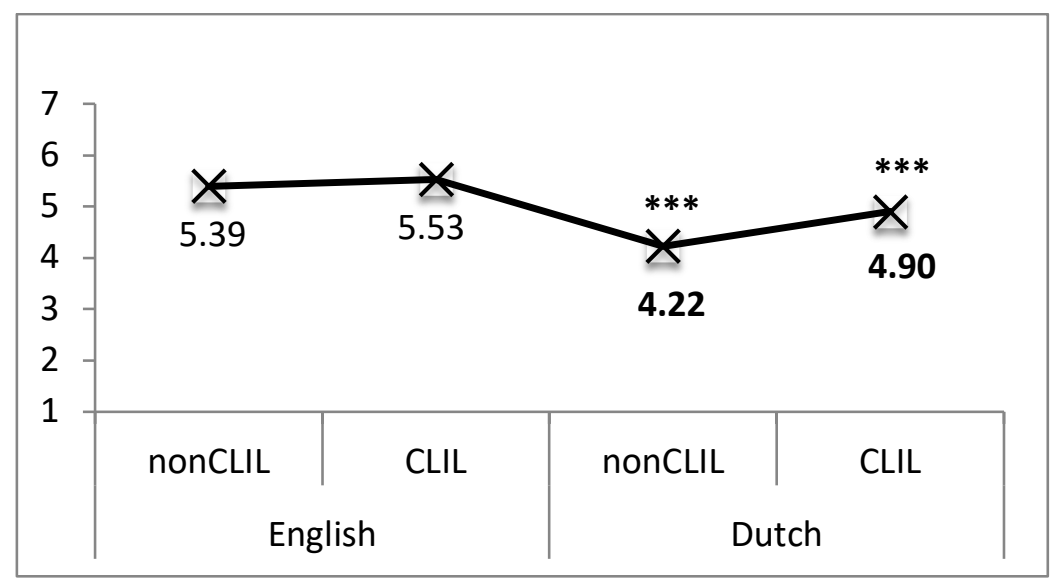

Figure 5 Interaction Approach $x$ TL for Value

\section{Discussion}

This study examines language attitudes and motivation in CLIL by looking into perceived easiness and attractiveness of the TL as well as expectancy for success, perceived task value and cost across different settings. The analyses of variance described above indicate significant differences between groups for the five attitudinal and motivational variables under scrutiny. In the following sections, we discuss and interpret the main differences according to (1) educational approach (CLIL/non-CLIL), 
(2) TL (English/Dutch) and (3) instruction level (primary/secondary), taking into account the significant interactions between groups.

\subsection{Differences according to educational approach (CLIL/non-CLIL)}

With respect to educational approach, our results confirm the hypothesis of more positive attitudes and higher motivation in CLIL compared to non-CLIL, even when controlling for several background differences (though not for baselines in attitude and motivation, see section on limitations). This is particularly the case for perceived easiness of the TL, which is significantly higher in CLIL than in nonCLIL across levels and TLs. This supports the idea that in CLIL pupils acquire a large degree of familiarity with the TL, which they then perceive as not difficult. Moreover, at primary level nonCLIL pupils were supposed to have just started with formal TL instruction when the data were collected, which might account for their increased feeling of difficulty. For the four other variables, significant interactions between approach and level indicate the differences in favor of CLIL only occur at secondary level, which means that CLIL and non-CLIL primary school pupils perceive the attractiveness of the $T L$, their expectancy for success, the task value and the cost of the learning in a similar way. Moreover, the interactions highlight a recurrent pattern for all variables (except perceived easiness of the TL): non-CLIL secondary school pupils present the most unfavorable attitudinal and motivational profiles, while primary school pupils display the most favorable profiles (see Figure 2 and Figure 4).

Furthermore, a last interaction reveals that for task value the advantage of CLIL pupils only appears for Dutch and not for English. The fact that the least favorable group of pupils is the nonCLIL group with Dutch as a TL can be explained by the strong correlation between perceived task value and attractiveness of the TL $\left(.640^{* * *}\right)$ : while learning English - a popular and global language is perceived as a highly valuable task by all pupils, regardless of the educational approach, learning Dutch - the language of the "other" community - is perceived as slightly more valuable by CLIL pupils than non-CLIL pupils (see Figure 5).

Although research on affective variables in CLIL is rather scarce, the findings for CLIL pupils are in line with the overall trend in the existing literature of more positive language attitudes and higher motivation in CLIL (see section 1.2). As to the fact that this benefit is mainly apparent at secondary school level, it ties up with the findings of Lasagabaster and López Beloqui (2015), who only found advantages of CLIL in primary school for some motivational constructs but not for others. A possible explanation lies in the tendency for language learning motivation to decrease over time (Chambers, 1999; Williams et al., 2002), especially in secondary education, as pupils undergo shifts in both identity and learning environment (Heras \& Lasagabaster, 2015; Wigfield, Eccles, \& Rodriguez, 1998). Our results indicate that CLIL might help to counter this downward tendency at secondary level. However, considering the indications of (self-)selection bias in CLIL (Bruton, 2011; Rumlich, 2014; Sylvén \& Thompson, 2015; Van Mensel et al., 2019), longitudinal analyses are needed to shed light on whether the more positive attitudes and higher motivation in CLIL are due to the approach or to initial differences.

\subsection{Differences according to target language (English/Dutch)}

Our findings also corroborate the hypothesis of more positive attitudes and higher motivation towards English than towards Dutch. This is particularly the case for perceived attractiveness of the TL and perceived task value, which are significantly higher for English than for Dutch regardless of the approach or level, though the difference between the TLs is considerably larger at secondary level. For the other three variables, the significant interactions between language and level also indicate the differences in favor of English only appear at secondary level, as there are no significant 
differences in primary school for perceived easiness of the TL, expectancy for success or cost. Moreover, these interactions between language and level uncover a consistent pattern: secondary school pupils learning English exhibit highly favorable attitudinal and motivational profiles, while secondary school pupils learning Dutch present the least favorable profiles (see Figure 1 and Figure 3).

The more positive attitudes and motivation in English compared to Dutch confirm the findings of previous research in the Belgian context (Mettewie, 2015) and highlight the importance of looking into other languages than the high-status, global English (see Ushioda \& Dörnyei, 2017), as results might differ according to the TL. Furthermore, our results reveal this benefit of English over Dutch is mainly noticeable at secondary level. This suggests that pupils learning English, just like CLIL pupils, are less prone to experiencing a decrease in motivation over time, in comparison with pupils learning Dutch. This is a valuable finding, as no studies - to our knowledge - have compared primary and secondary school pupils' language attitudes and motivation towards different TLs.

Interestingly, our results also show the effect of TL is much larger than the effect of educational approach, for all variables except perceived easiness of the TL (see Table 4 and Table 6). Most noteworthy is the very large effect size of perceived attractiveness of the TL $\left(\eta^{2}{ }_{p}=.381\right)$, followed by task value $\left(\eta^{2}{ }_{p}=.148\right)$, cost $\left(\eta^{2}{ }_{p}=.061\right)$ and expectancy for success $\left(\eta_{p}{ }_{p}=.034\right)$. These preponderant effect sizes of TL put the potential benefit of CLIL into perspective. While our results suggest CLIL might help to counter the tendency of affective variables decreasing over time, pupils report particularly low attractiveness of Dutch in secondary education (below the neutral point of 4), even in CLIL ( $M=3.88$, see Table 2). This indicates that TL outweighs educational approach when it comes to pupils' motivation and language attitudes (at least in terms of perceived attractiveness).

\subsection{Differences according to instruction level (primary/secondary)}

As to instruction level, our results indicate a less clear-cut pattern. We hypothesized more positive attitudes and higher motivation in primary compared to secondary education, based on the wellknown tendency for motivation to decrease over the course of education. While our hypothesis was confirmed for attractiveness of the $\mathrm{TL}$, expectancy for success and task value, we found no significant difference between the two instruction levels for perceived cost. Moreover, our results show pupils perceive the TL as easier at secondary than primary level. This probably reflects the higher language mastery of secondary school pupils in comparison to primary school pupils, especially non-CLIL primary pupils, who are supposed to have just started the instructed language learning process at the time of the data collection.

Nevertheless, a significant interaction with TL reveals that the higher perceived easiness at secondary level only applies to English, suggesting Dutch is not seen as easier with experience (see Figure 1). In contrast, the other significant interactions between level and TL indicate only pupils learning Dutch report higher attractiveness, expectancy for success and task value at primary (see Figure 1 and Figure 3), whereas there are no significant differences for pupils with English as a TL at primary or secondary school. This again suggests that pupils learning English do not suffer equally from decrease in motivation and positive attitudes, compared to those learning Dutch, but also that pupils starting to learn Dutch through formal instruction in the fifth grade of primary school are still fairly unprejudiced against Dutch, compared to secondary school.

Finally, the significant interactions with educational approach show that only non-CLIL pupils at secondary level report lower motivational profiles, while CLIL pupils perceive expectancy and task value of the learning process as quite high across primary and secondary education (see Figure 4).

Overall, these findings underscore the importance of integrating different instruction levels, as different tendencies emerge. Most effects of TL and educational approach only appear at secondary level, whereas primary school pupils seem to have similar attitudes and motivation regardless of the 
$T L$ (except for task value and attractiveness of the $T L$ ) and of the educational approach. This suggests that differences appear or increase after the fifth grade, which is the compulsory onset of formal TL learning at school for non-CLIL pupils in this sample.

\section{Limitations}

Despite the large number of variables included in the analyses, this study has limitations. One of them being the lack of control we had on the individual language learning trajectories (both in CLIL and non-CLIL) and the degrees of exposure to the TL (at school and outside school). Though we tried to collect this information, the diversity in profiles did not allow us at this stage to include these in the quantitative analyses. Limiting the sample to those reporting the expected clear-cut starting points and limiting the degree of exposure to school only would have reduced the number of participants drastically and dismissed the natural diversity present within language classrooms. Another limitation of this study is its cross-sectional design. With no measure of the initial level of motivation and attitude, it is impossible to know if the observed differences between CLIL and nonCLIL pupils are due to pre-existing differences or to the CLIL instructional approach. However, within the framework of our project, longitudinal data have been collected in order to try to better identify the role of the CLIL approach. This will be part of future research, as well as more detailed analyses concerning the possible role of schools, contact with the target community or perceived conflict within the Belgian context and measures of language competence.

\section{Conclusion}

The findings of this study indicate that pupils attending a CLIL track have slightly more favorable motivational profiles than those in non-CLIL, with higher expectancy for success, higher perceived task value and lower cost in learning the TL. This is also the case at the attitudinal level, as CLILpupils perceive their TL as easier and more attractive than non-CLIL pupils. The results also highlight that attitudes and motivation regarding English (the global, international language) are clearly more favorable than those towards Dutch (the language of the other main Belgian community). Hence, both findings support previous research trends, but on a larger scale. However, the present study reveals that differences in favor of CLIL and English mainly appear at secondary school level. This finding suggests that pupils' language attitudes and motivation are less likely to decrease over time in CLIL and in English, in comparison with non-CLIL pupils and pupils learning Dutch. Nonetheless, this should be verified through future longitudinal analyses.

While the CLIL literature largely focuses on English, the comparison of two TLs in this study suggests CLIL might be more beneficial for languages other than English. Our findings show that task value of Dutch is significantly higher in CLIL than in non-CLIL, whereas task value of English is perceived as very high regardless of the educational approach. In fact, TL (English vs. Dutch) appears to have a much larger effect than educational approach (CLIL or non-CLIL) on motivation and language attitudes (except for perceived easiness of the $\mathrm{TL}$ ). This highlights the impact of the status of the TL, as clearly illustrated by the differences in perceived attractiveness of English and Dutch.

In sum, this study's application of the expectancy-value model, on two TLs, combined with a focus on attitudes towards these TLs themselves (particularly perceived attractiveness), constitutes a novel approach in the context of CLIL and provides interesting insights from both a methodological and societal point of view. It reinforces the idea that CLIL, if its benefits are confirmed, also serves a sociocultural purpose (Eurydice, 2006), especially regarding languages with a less favorable status, which is particularly valuable in tense linguistic contexts such as Belgium. At the same time, the larger effect sizes for the TLs suggest that the role of the CLIL approach should, on the basis of this 
study, not be overestimated, as other individual or contextual factors might play a more fundamental role in shaping language attitudes and motivation.

\section{Acknowledgments}

This work was supported by a Concerted Research Action grant (ARC 14/19-061) awarded to Philippe Hiligsmann (spokesman; UCLouvain), Benoît Galand (UCLouvain), Laurence Mettewie (UNamur), Fanny Meunier (UCLouvain), Arnaud Szmalec (UCLouvain) and Kristel Van Goethem (UCLouvain). We thank Amélie Bulon, Isa Hendrikx and Morgane Simonis for their assistance in the data collection.

\section{References}

Amengual-Pizzaro, M., \& Prieto-Arranz, J. I. (2014). Exploring affective factors in L3 learning: CLIL vs. Non-CLIL. In M. Juan-Garau \& J. Salazar-Noguera, Content-based Language Learning in Multilingual Educational Environments (pp. 197-220). Springer.

Baker, C. (1992). Attitudes and Language. Multilingual Matters.

Bandura, A. (1977). Self-efficacy: Toward a unifying theory of behavioral change. Psychological Review, 84(2), 191-215. https://doi.org/10.1037/0033-295X.84.2.191

Banegas, D. L. (2012). Motivation and autonomy through CLIL. A collaborative undertaking. In L. Anglada \& D. L. Banegas (Eds.), Selected papers from the XXXVII FAAPI Conference (pp. 39-45). Bariloche: APIZALS Asociación de Profesores de Inglés de la Zona Andina y Línea Sur.

Barron, K. E., \& Hulleman, C. S. (2015). Expectancy-value-cost model of motivation. In J. D. Wright (Ed.), International Encyclopedia of Social and Behavioral Sciences (2nd Edition, Vol. 8, pp. 503509). Oxford, UK: Elsvier.

Bohner, G. (2003). Attitudes. In M. Hewstone \& W. Stroebe, Introduction to Social Psychology. A European Perspective (pp. 239-282). Oxford: Blackwell Publishers.

Bruton, A. (2011). Is CLIL so beneficial, or just selective? Re-evaluating some of the research. System, 39(4), 523-532. https://doi.org/10.1016/j.system.2011.08.002

Chambers, G. N. (1999). Motivating Language Learners. Clevedon, UK: Multilingual Matters.

Coonan, C. M. (2012). Affect and motivation in CLIL. In D. Marsh \& O. Meyer (Eds.), Quality Interfaces: Examining Evidence \& Exploring Solutions in CLIL (pp. 53-66). Eichstaett: Eichstaett Academic Press.

Coyle, D. (2005). Developing CLIL: Towards a Theory of Practice. In N. Figueras (Ed.), CLIL in Catalonia, from Theory to Practice (pp. 5-29). Barcelona.

Dalton-Puffer, C. (2008). Outcomes and processes in Content and Language Integrated Learning (CLIL): Current research from Europe. In Future Perspectives for English Language Teaching (pp. 139-157).

Davies, J., \& Brember, I. (2001). The closing gap in attitudes between boys and girls: A five year longitudinal study. Educational Psychology, 21(1), 103-115.

https://doi.org/10.1080/01443410124899

De Smet, A. (2012). "L'immersion c'est pour quelqu'un qui parle bien néerlandais". CLIL bij oudere 
leerlingen (Unpublished). Vrije Universiteit Brussel, Brussel.

De Smet, A., Mettewie, L., Galand, B., Hiligsmann, P., \& Van Mensel, L. (2018). Classroom anxiety and enjoyment in CLIL and non-CLIL: Does the target language matter? Studies in Second Language Learning and Teaching, 8(1), 47-71. https://doi.org/10.14746/ssllt.2018.8.1.3

Deci, E. L., \& Ryan, R. M. (1985). Intrinsic motivation and self-determination in human behavior. New York: Plenum.

Denman, J., Tanner, R., \& de Graaff, R. (2013). CLIL in junior vocational secondary education: Challenges and opportunities for teaching and learning. International Journal of Bilingual Education and Bilingualism, 16(3), 285-300. https://doi.org/10.1080/13670050.2013.777386

Dewaele, J.-M. (2005). Sociodemographic, psychological and politicocultural correlates in Flemish students' attitudes towards French and English. Journal of Multilingual and Multicultural Development, 26(2), 118-137. https://doi.org/10.1080/01434630508668400

Doiz, A., Lasagabaster, D., \& Sierra, J. M. (2014a). CLIL and motivation: The effect of individual and contextual variables. The Language Learning Journal, 42(2), 209-224.

https://doi.org/10.1080/09571736.2014.889508

Doiz, A., Lasagabaster, D., \& Sierra, J. M. (2014b). Giving voice to the students: What (de)motivates them in CLIL classes? In D. Lasagabaster, A. Doiz, \& J. M. Sierra (Eds.), Language Learning \& Language Teaching (Vol. 40, pp. 117-138). https://doi.org/10.1075/IIt.40.06doi

Dörnyei, Z. (2005). The psychology of the language learner: Individual differences in second language acquisition. Mahwah, N.J.: L. Erlbaum.

Dörnyei, Z. (2009). The L2 motivational self system. In Z. Dörnyei \& E. Ushioda (Eds.), Motivation, language identity and the L2 self (pp. 9-11). Bristol: Multilingual Matters.

Dörnyei, Z. (2019). Psychology and Language Learning: The Past, the Present and the Future. Journal for the Psychology of Language Learning, 1, 27-41.

Entwisle, D. R., \& Astone, N. M. (1994). Some Practical Guidelines for Measuring Youth's Race/Ethnicity and Socioeconomic Status. Child Development, 65(6), 1521-1540.

https://doi.org/10.1111/j.1467-8624.1994.tb00833.x

European Commission. (2014). Improving the effectiveness of language learning: CLIL and computer assisted language learning.

Eurydice. (2006). Content and language integrated learning (CLIL) at school in Europe. Bruxelles: Eurydice European Unit.

Fernández Fontecha, A., \& Canga Alonso, A. (2014). A preliminary study on motivation and gender in CLIL and non-CLIL types of instruction. International Journal of English Studies, 14(1), 21-36.

Galand, B., \& Hospel, V. (2015). Facteurs associés au risque de décrochage scolaire: Vers une approche intégrative. L'orientation scolaire et professionnelle, 44(3).

https://doi.org/10.4000/osp.4604

Gardner, R. C. (1985). Social Psychology and Second Language Learning. The Role of Attitudes and Motivation. London: Edward Arnold.

Gardner, R. C., \& Lambert, W. E. (1959). Motivational variables in second language acquisition. Canadian Journal of Psychology, 13(4), 266-272. https://doi.org/10.1037/h0083787

Gardner, R. C., \& Lambert, W. E. (1972). Attitudes and Motivation in Second-Language Learning. 
Rowley, Massachusetts: Newbury House.

Garrett, P., Coupland, N., \& Williams, A. (2003). Investigating language attitudes: Social meanings of dialect, ethnicity and performance. Cardiff: University of Wales Press.

Harrop, E. (2012). Content and language integrated learning (CLIL): Limitations and possibilities. Encuentro, 21, 57-70.

Heras, A., \& Lasagabaster, D. (2015). The impact of CLIL on affective factors and vocabulary learning. Language Teaching Research, 19(1), 70-88. https://doi.org/10.1177/1362168814541736

Higgins, E. T. (1987). Self-discrepancy: A theory relating self and affect. Psychological Review, 94(3), 319-340. https://doi.org/10.1037/0033-295X.94.3.319

Hiligsmann, P., Van Mensel, L., Galand, B., Mettewie, L., Meunier, F., Szmalec, A., ... Simonis, M. (2017). Assessing Content and Language Integrated Learning (CLIL) in French-speaking Belgium: Linguistic, cognitive and educational perspectives. Les Cahiers de Recherche Du Girsef, 109, 1-24.

Hunt, M. (2011). Learners' perceptions of their experiences of learning subject content through a foreign language. Educational Review, 63(3), 365-378.

https://doi.org/10.1080/00131911.2011.571765

Kormos, J., Kiddle, T., \& Csizér, K. (2011). Goals, attitudes and self-related beliefs in second language learning motivation: An interactive model of language learning motivation. Applied Linguistics, 32(5), 495-516. https://doi.org/10.1093/applin/amr019

Lasagabaster, D. (2009). The Implementation of CLIL and Attitudes towards Trilingualism. ITL International Journal of Applied Linguistics, 157(0), 23-43.

https://doi.org/10.2143/ITL.157.0.2042586

Lasagabaster, D. (2011). English achievement and student motivation in CLIL and EFL settings. Innovation in Language Learning and Teaching, 5(1), 3-18.

https://doi.org/10.1080/17501229.2010.519030

Lasagabaster, D., \& Doiz, A. (2017). A Longitudinal Study on the Impact of CLIL on Affective Factors. Applied Linguistics, 38, 688-712. https://doi.org/10.1093/applin/amv059

Lasagabaster, D., \& López Beloqui, R. (2015). The Impact of Type of Approach (CLIL versus EFL) and Methodology (Book-Based versus Project Work) on Motivation. Porta Linguarum: Revista Internacional de Didáctica de Las Lenguas Extranjeras, (23), 41-57.

Lasagabaster, D., \& Sierra, J. M. (2009). Language Attitudes in CLIL and Traditional EFL Classes. International CLIL Research Journal, 1, 4-17.

Lochtman, K., Lutjeharms, M., \& Kermarrec, G. (2005). Langues étrangères à Bruxelles: Recherche sur les attitudes d'étudiants Bruxellois des écoles d'ingénieur commercial ULB et VUB. In E. Witte, L. Van Mensel, M. Pierrard, L. Mettewie, A. Housen, \& R. De Groof (Eds.), Language, attitudes and education in multilingual cities (pp. 211-233). Brussels: Koninklijke Vlaamse Academie van België voor Wetenschappen en Kunst.

Maclntyre, P. D., \& Blackie, R. A. (2012). Action control, motivated strategies, and integrative motivation as predictors of language learning affect and the intention to continue learning French. System, 40(4), 533-543. https://doi.org/10.1016/j.system.2012.10.014

Markus, H., \& Nurius, P. (1986). Possible selves. American Psychologist, 41(9), 954-969. https://doi.org/10.1037/0003-066X.41.9.954 
Masgoret, A.-M., \& Gardner, R. C. (2003). Attitudes, motivation, and second language learning: A meta-analysis of studies conducted by Gardner and associates. Language Learning, 167-210. https://doi.org/10.1111/1467-9922.00227

Mearns, T., de Graaff, R., \& Coyle, D. (2017). Motivation for or from bilingual education? A comparative study of learner views in the Netherlands. International Journal of Bilingual Education and Bilingualism, 1-14. https://doi.org/10.1080/13670050.2017.1405906

Mettewie, L. (2004). Attitudes en motivatie van taalleerders in België. Vrije Universiteit Brussel, Brussel. Available at https://researchportal.unamur.be/fr/publications/attitudes-en-motivatievan-taalleerders-in-belgië

Mettewie, L. (2015). Apprendre la langue de "I'Autre" en Belgique: La dimension affective comme frein à l'apprentissage. Le Langage et l'Homme, 50(2), 23-42.

Mettewie, L., \& Janssens, R. (2007). Language Use and Language Attitudes in Brussels. In Multilingualism in European Bilingual Contexts: Language Use and Attitudes (pp. 117-143). Multilingual Matters.

Mettewie, L., \& Lorette, P. (2014). Tweetalig onderwijs als Belgische "philtre d'amour". Attitudes van Franstalige CLIL-leerders van het Nederlands. In L. Degand, P. Hiligsmann, L. Rasier, M. Sergier, S. Vanasten, \& K. Van Goethem (Eds.), In het teken van identiteit: Taal en cultuur van de Nederlanden (pp. 195-201). Louvain-la-Neuve: Presses Universitaires de Louvain.

Mills, N., Pajares, F., \& Herron, C. (2006). A reevaluation of the role of anxiety: Self-efficacy, anxiety, and their relation to reading and listening proficiency. Foreign Language Annals, 39(2), 276-295. https://doi.org/10.1111/j.1944-9720.2006.tb02266.x

Mills, N., Pajares, F., \& Herron, C. (2007). Self-efficacy of college intermediate French students: Relation to achievement and motivation. Language Learning, 57(3), 417-442.

https://doi.org/10.1111/j.1467-9922.2007.00421.x

Navarro-Villarroel, C. (2011). Young students' attitudes toward languages (lowa State University). Retrieved from http://lib.dr.iastate.edu/etd/11978/

Noels, K. A., Pelletier, L. G., Clément, R., \& Vallerand, R. J. (2000). Why are you learning a second language? Motivational orientations and self-determination theory. Language Learning, 50(1), 5785. https://doi.org/10.1111/0023-8333.00111

Piniel, K., \& Csizér, K. (2013). L2 motivation, anxiety and self-efficacy: The interrelationship of individual variables in the secondary school context. Studies in Second Language Learning and Teaching, 3(4), 523-550. https://doi.org/10.14746/ssllt.2013.3.4.5

Raven, J. C., Court, J. H., \& Raven, J. (1998). Progressive Coloured Matrices. Oxford: Oxford Psychologists Press.

Rumlich, D. (2014). Prospective CLIL and non-CLIL students' interest in English (classes): A quasiexperimental study on German sixth-graders. In R. Breeze (Ed.), Integration of theory and practice in CLIL (pp. 75-95). Amsterdam.

Seikkula-Leino, J. (2007). CLIL Learning: Achievement Levels and Affective Factors. Language and Education, 21(4), 328-341. https://doi.org/10.2167/le635.0

Sharp, D., Thomas, B., Price, E., Francis, G., \& Davies, I. (1973). Attitudes to Welsh and English in the Schools of Wales. Basingstoke/Cardiff: Macmillan/University of Wales Press.

Sierra, J. M. (2011). CLIL and project work: Contributions from the classroom. In Y. Ruiz de Zarobe, 
J. M. Sierra, \& F. Gallardo del Puerto (Eds.), Content and foreign language integrated learning: Contributions to multilingualism in European contexts (pp. 211-239). Bern: Peter Lang.

Simonis, M., Van der Linden, L., Galand, B., Hiligsmann, P., \& Szmalec, A. (2019). Executive control performance and foreign-language proficiency associated with immersion education in Frenchspeaking Belgium. Bilingualism: Language and Cognition, 1-16.

https://doi.org/10.1017/S136672891900021X

Sylvén, L. K., \& Thompson, A. S. (2015). Language learning motivation and CLIL: Is there a connection? Journal of Immersion and Content-Based Language Education, 3(1), 28-50. https://doi.org/10.1075/jicb.3.1.02syl

Ushioda, E., \& Dörnyei, Z. (Eds.). (2017). Special Issue. Beyond Global English: Motivation to learn languages in a multicultural world. The Modern Language Journal, 101(3), 449-607.

Van de Craen, P., Surmont, J., Mondt, K., \& Ceuleers, E. (2012). Twelve years of CLIL practice in multilingual Belgium. In C. Lechner \& G. Egger (Eds.), Primary CLIL around Europe: Learning in two languages in primary education (pp. 81-97). Marburg: Tectum.

Van Mensel, L., Hiligsmann, P., Mettewie, L., \& Galand, B. (2019). CLIL, an elitist language learning approach? A background analysis of English and Dutch CLIL pupils in French-speaking Belgium. Language, Culture and Curriculum, 1-14. https://doi.org/10.1080/07908318.2019.1571078

Wigfield, A., \& Cambria, J. (2010). Expectancy-value theory: Retrospective and prospective. In T. C. Urdan \& S. A. Karabenick (Eds.), Advances in Motivation and Achievement (Vol. 16, pp. 35-70). https://doi.org/10.1108/S0749-7423(2010)000016A005

Wigfield, A., \& Eccles, J. S. (2000). Expectancy-Value Theory of Achievement Motivation. Contemporary Educational Psychology, 25(1), 68-81. https://doi.org/10.1006/ceps.1999.1015

Wigfield, A., Eccles, J. S., \& Rodriguez, D. (1998). Chapter 3: The Development of Children's Motivation in School Contexts. Review of Research in Education, 23(1), 73-118. https://doi.org/10.3102/0091732X023001073

Williams, M., Burden, R., \& Lanvers, U. (2002). 'French is the language of love and stuff': Student perceptions of issues related to motivation in learning a foreign language. British Educational Research Journal, 28(4), 503-528. https://doi.org/10.1080/0141192022000005805 


\section{APPENDIX}

\section{Scales (French version used in the study)}

Attractiveness of the target language: 3 items $(\alpha=.877)$

1. Je trouve le néerlandais/l'anglais une langue laide - belle

2. Je trouve le néerlandais/I'anglais une langue désagréable - agréable à l'oreille

3. Je trouve le néerlandais/l'anglais une langue ringarde - moderne, cool

Easiness of the target language: 6 items ( $\alpha=.835)$

1. Je trouve le néerlandais/l'anglais une langue difficile - facile à comprendre

2. Je trouve le néerlandais/l'anglais une langue difficile - facile à lire

3. Je trouve le néerlandais/l'anglais une langue difficile - facile à parler

4. Je trouve le néerlandais/l'anglais une langue difficile - facile à prononcer

5. Je trouve le néerlandais/l'anglais une langue difficile - facile à écrire

6. Je trouve le néerlandais/l'anglais une langue avec une grammaire difficile - facile

Expectancy for success: 5 items $(\alpha=.759)$

1. Par rapport aux autres élèves de cette classe, je pense que je suis doué(e) en néerlandais/ anglais.

2. Je sais que je suis capable d'apprendre le néerlandais/l'anglais si je le veux vraiment.

3. Je pense que je suis bon(ne) en néerlandais/anglais.

4. Si on me laisse assez de temps, je suis capable de bien réussir en néerlandais/anglais.

5. Si je fais les efforts nécessaires, je suis capable de bien maîtriser le néerlandais/anglais.

Perceived task value: 8 items $(\alpha=.854)$

1. Je veux apprendre le néerlandais/l'anglais, parce que je me sens bien quand je parle cette langue.

2. Apprendre le néerlandais/l'anglais m'intéresse beaucoup.

3. J'ai du plaisir à parler le néerlandais/l'anglais.

4. J'ai envie d'en apprendre plus en néerlandais/anglais.

5. Apprendre le néerlandais/l'anglais m'est utile dans la vie de tous les jours.

6. Apprendre le néerlandais/l'anglais me permet de mieux exprimer mes idées en général.

7. C'est important pour moi d'apprendre le néerlandais/l'anglais, parce que je veux être une personne multilingue.

8. Savoir m'exprimer en néerlandais/anglais est essentiel pour ce que j'ai envie de faire plus tard.

Cost: 3 items ( $\alpha=.711$ )

1. L'apprentissage du néerlandais/de l'anglais me demande trop d'énergie pour ce que cela m'apporte.

2. Apprendre le néerlandais/l'anglais m'empêche de faire trop d'autres choses que j'aime.

3. Améliorer mon néerlandais/anglais me demanderait trop de temps et de sacrifices. 